\title{
PERAN BIDAN SEBAGAI FASILITATOR PELAKSANAAN PROGRAM PERENCANAAN PERSALINAN DAN PENCEGAHAN KOMPLIKASI (P4K) DI WILAYAH PUSKESMAS KABUPATEN PEKALONGAN
}

\author{
Putri Andanawarih ${ }^{1}$, Ida Baroroh ${ }^{2}$ \\ e-mail : poetry andana@yahoo.com \\ ${ }^{1,2,}$ Akademi Kebidanan Harapan Ibu Pekalongan \\ J1. Sriwijaya No 7 Kota Pekalongan \\ Telp 085102998866
}

\begin{abstract}
Abstrak
Kehamilan dan persalinan adalah suatu hal yang alami akan tetapi bukan berarti tanpa resiko, masalah kehamilan dan persalinan adalah penyumbang terbesar Angka Kematian Ibu dan Angka Kematian Bayi. Salah satu masalah kesehatan di Indonesia adalah tingginya Angka Kematian Ibu (AKI), di Kota Pekalongan 80,19/100 KH(2010), 145,68/100KH(2011), dan 81,97/100KH(2012). Upaya untuk menurunkan AKI dengan Program Perencanaan Persalinan dan Pencegahan Komplikasi (P4K). Bidan puskesmas merupakan tenaga kesehatan yang paling strategis dalam pelaksanaan layanan kesehatan masyarakat, serta paling tepat dalam melaksanakan peran fasilitator dalam P4K.. Penelitian untuk mengetahui gambaran umum Peran Bidan Sebagai Fasilitator Pelaksanaan P4K di wilayah Puseksmas Kabupaten Pekalongan. Desain penelitian menggunakan penelitian deskriptif. Populasi yang digunakan adalah bidan puskesmas di wilayah Kabupaten Pekalongan. Sampel yang digunakan adalah sampel jenuh sebanyak 57 bidan, dengan pengambilan data menggunakan observasi. Analisis data menggunakan variabel karakteristik bidan yaitu umur dan pendidikan bidan, serta implementasi pelaksanaan P4K oleh bidan yang meliputi: pendataan, perencanaan, sosialisasi, pelayanan, dan kerjasama tim. Hasil penelitian menunjukkan bidan berperan dalam pendataan ibu hamil disertai pemberian stiker sebanyakl $(91,2 \%)$, perencanaan persalinan $(89,5 \%)$, sosialisasi dengan melibatkan lintas sektor $(91,2 \%)$, konseling pada ibu hamil $(84,2 \%)$ serta kerjasama tim dalam pelaksanaan P4K sebesar $(71,9 \%)$.
\end{abstract}

Kata Kunci : Peran Bidan, Fasilitator, $P 4 K$

\section{Pendahuluan}

Angka Kematian Ibu (AKI) dan Angka Kematian bayi (AKB) merupakan indikator penting untuk menilai tingkat kesejahteraan suatu Negara dan status kesehatan masyarakat. Kematian ibu merupakan kematian seorang wanita yang terjadi saat hamil, bersalin, dan masa nifas (dalam 42 hari) setelah persalinan. Kematian yang berkaitan dengan kehamilan merupakan masalah yang sampai saat ini belum dapat diatasi. Hal ini terlihat dari masih tingginya angka kematian yang berkaitan dengan masalah kehamilan, seperti AKI dan AKB di berbagai belahan dunia. WHO (World Health Organization) melaporkan bahwa AKI secara global sebesar 220/100.000 kelahiran hidup, sedangkan di Indonesia AKI sebesar 210/100.000 kelahiran hidup. AKB tahun 2010 secara global sebesar 40/1.000 kelahiran hidup, sedangkan di Indonesia sebesar 27/1.000 kelahiran hidup (1).
Angka Kematian Ibu (AKI) di Provinsi Jawa Tengah pada tahun 2015 masih termasuk tinggi yaitu sebanyak 619 kasus, mengalami penurunan yang cukup signifikan dibandingkan dengan tahun 2014 yang mencapai 711 kasus. Sedangkan AKI di Kabupaten Pekalongan tahun 2015 sebanyak 22 kasus $^{(2)}$.

Menurut Survei Demografi dan Kependudukan Indonesia oleh BKKBN dalam Diadjeng Setya Wardani $(2009)^{(3)}$. Penyebab kematian ibu terbesar secara berurutan disebabkan terjadinya perdarahan, eklamsia, infeksi, persalinan lama dan keguguran. Kematian bayi sebagian besar disebabkan karena Bayi Berat Lahir Rendah (BBLR), kesulitan bernafas saat lahir dan infeksi. Permasalahan tingginya Angka Kematian Ibu ini perlu mendapat perhatian penting oleh Dinas Kesehatan dengan melaksanakan program perbaikan dan peningkatan kesehatan ibu. Upaya penurunan kematian ibu dan bayi dapat dilakukan dengan peningkatan cakupan dan 
kualitas pelayanan kesehatan ibu dan anak. Salah satu upaya yang dilakukan adalah mendekatkan jangkauan pelayanan kesehatan kepada masyarakat melalui Program Perencanaan Persalinan dan Pencegahan Komplikasi (P4K) ${ }^{(4)}$.

Bidan memiliki peran penting dalam pelaksanaan Program Perencanaan Persalinan dan Pencegahan Komplikasi (P4K) yaitu melakukan pendataan ibu hamil untuk mengetahui jumlah ibu hamil dan untuk merencanakan persalinan yang aman, persiapan menghadapi komplikasi dan tanda bahaya ke bidan bagi ibu sehingga melahirkan bayi yang sehat dan ibu selamat dengan mengikutsertakan suami dan keluarga. Serta menggerakkan masyarakat dengan memberikan penyuluhan dan mengadakan pertemuan tiap bulan, mengikutsertakan masyarakat seperti: tokoh masyarakat, tokoh agama, kader dan dukun bayi. Keikutsertaan masyarakat akan mempercepat terlaksananya program peningkatan mutu kesehatan dan tertanganinya resiko yang ada dengan cepat dan tepat ${ }^{(4)}$.

Salah satu alasan P4K dilaksanakan di Kabupaten Pekalongan untuk mengurangi angka kematian ibu yang biasanya terjadi karena tidak memiliki akses ke pelayanan kesehatan yang berkualitas, terutama pelayanan kegawatdaruratan tepat waktu yang dilatarbelakangi oleh terlambat mengenal tanda bahaya dan mengambil keputusan, terlambat mencapai fasilitas tenaga kesehatan, serta terlambat mendapatkan pelayanan di fasilitas kesehtan ${ }^{(5)}$

Tujuan penelitian ini Untuk memperoleh gambaran tentang Peran Bidan Sebagai Fasilitator Pelaksanaan Program Perencanaan Persalinan dan Pencegahan Komplikasi (P4K) di Wilayah Puskesmas Kabupaten Pekalongan.

\section{Metode Penelitian}

Metode penelitian yang digunakan adalah deskriptif kuantitatif, dengan tujuan utamanya mengetahui sejauh mana implementasi Pelaksanaan P4K oleh bidan sebagai Fasilitator di Puskesmas Kabupaten Pekalonga yang dilaksanakan pada bulan September - Desember 2016. Populasi dalam penelitian ini adalah bidan Puskesmas di Wilayah Kabupaten
Pekalongan sebanyak 277 bidan. Sampel yang diambil menggunakan sistem accidental sampling dan didapatkan sampel sebanyak 57 orang yang memenuhi kriteria sebagai berikut : 1) Bidan Puskesmas dengan wilayah kerja di Kabupaten Pekalongan 2) Bidan yang bersedia menjadi responden.

Data penelitian diambil menggunakan quesioner tertutup yang berisi pertanyaan dan disediakan jawaban dalam bentuk variasi "Ya" atau "Tidak".Data yang didapatkan kemudian dilakukan analisis menggunakan analisis univariat.

\section{Hasil dan Pembahasan}

Karakteristik responden dalam penelitian ini menujukkan sebagian besar berumur kurang dari 40 tahun sebanyak 53 bidan, selebihnya 4 bidan berusia kurang dari 40 tahun. Bidan puskesmas di Kabupaten Pekalongan sebagian besar menunjukkan tingkat pendidikan lulusan D.III, yaitu sebanyak 49 bidan $(57,6 \%)$, dan selanjutnya D.I ada 7 bidan (12,28\%), D.IV 1 bidan $(1,75 \%)$.

Tabel 1 Distribusi Pendataan dalam Pelaksanaan P4K

\begin{tabular}{|c|c|c|c|c|c|}
\hline \multirow[b]{2}{*}{$\begin{array}{l}\mathrm{N} \\
\mathrm{o}\end{array}$} & \multirow{2}{*}{$\begin{array}{l}\text { Peran Bidan } \\
\text { dalam } \\
\text { pendataan }\end{array}$} & \multicolumn{2}{|c|}{$\mathrm{Ya}$} & \multicolumn{2}{|c|}{ Tidak } \\
\hline & & (f) & $\%$ & (f) & $\%$ \\
\hline 1 & $\begin{array}{l}\text { Semua ibu hamil } \\
\text { terdata oleh bidan }\end{array}$ & 52 & 91.2 & 5 & 8.8 \\
\hline 2 & $\begin{array}{l}\text { Semua ibu hamil } \\
\text { rumahnya } \\
\text { tertempel stiker } \\
\text { pendataan. }\end{array}$ & 51 & 89.5 & 6 & 10.5 \\
\hline 3 & $\begin{array}{l}\text { Bidan melakukan } \\
\text { update pendataan } \\
\text { ibu hamil selama } \\
\text { sebulan sekali. }\end{array}$ & 54 & 94.7 & 3 & 5.3 \\
\hline
\end{tabular}

Sebanyak 52 bidan menyatakan telah melakukan pendataan ibu hamil sesuai wilayah kerjanya, namun masih ada 5 bidan yang tidak mendata keseluruhan ibu hamil di wilayah kerjanya.Sehingga data ibu hamil yang masuk ke Puskesmas sesuai wilayah kerja bidan tersebut tidak mencapai seratus persen. Namun tidak semua yang terdata diberi/tempel stiker pendataan, hanya 51 bidan (89.5\%) yang memberikan jawaban "ya" pada peran tersebut. Bidan (94.7\%) juga melaksanakan pendataan ulang setiap 
sebulan sekali. Pendataan yang dilengkapi dengan penempelan stiker pada masingmasing rumah ibu hamil merupakan langkah notifikasi sasaran dalam rangka meningkatkan cakupan mutu pelayanan kesehatan bagi ibu dan bayi baru lahir ${ }^{(6)}$. Pembaharuan dan kelengkapan data ibu hamil menjadi faktor penting tercapainya sasaran pelayanan bidan dalam pelaksanaan P4K. Peneliti berpendapat dengan adanya up-date sebulan sekali, maka diharapkan tidak ada ibu hamil yang tak terdata atau terlayani dalam masa kehamilan hingga persalinan.

Tabel 2 Distribusi Perencanaan dalam pelaksanaan P4K

\begin{tabular}{|c|c|c|c|c|c|}
\hline \multirow{2}{*}{$\begin{array}{l}\mathrm{N} \\
\mathrm{O}\end{array}$} & \multirow{2}{*}{$\begin{array}{l}\text { Peran Bidan dalam } \\
\text { perencanaan }\end{array}$} & \multicolumn{2}{|c|}{$\mathrm{Ya}$} & \multicolumn{2}{|c|}{ Tidak } \\
\hline & & (f) & $\%$ & (f) & $\%$ \\
\hline 1 & $\begin{array}{l}\text { Ibu hamil dan } \\
\text { keluarganya } \\
\text { merencanakan } \\
\text { persalinan yang } \\
\text { dibuat bersama } \\
\text { dengan bidan }\end{array}$ & 51 & 89.5 & 6 & 10.5 \\
\hline 2 & $\begin{array}{l}\text { Ibu hamil dan } \\
\text { keluarganya } \\
\text { mempunyai rencana } \\
\text { menggunakan KB } \\
\text { yang dibuat } \\
\text { bersama bidan }\end{array}$ & 43 & 75.4 & 14 & 24.6 \\
\hline 3 & $\begin{array}{l}\text { Membuat rencana } \\
\text { pendanaan } \\
\text { persalinan seperti } \\
\text { Tabulin/Dasolin }\end{array}$ & 41 & 71.9 & 16 & 28.1 \\
\hline
\end{tabular}

Rata-rata $\quad(89,5 \%) \quad$ ibu hamil merencanakan persalinannya yang dipandu oleh bidan. Namun untuk rencana pendanaan persalinan tidak semua ibu hamil merencanakannya bersama bidan, hanya ada 41 atau $71,9 \%$. Perencanaan persalinan dilakukan antara ibu hamil, keluarga dan bidan. Dalam hal ini bidan memberikan panduan akan hal-hal penting yang perlu dipersiapkan selama kehamilan dan menjelang kelahiran. Adanya rencana persalinan aman yang disepakati bersama antara ibu hamil, suami dan keluarga dengan bidan, merupakan tujuan dari $\mathrm{P} 4 \mathrm{~K}^{(7)}$. Bidan memahami hal tersebut dan gambaran yang didapat dari responden sebagian besar $(89,5 \%)$ telah memberikan dukungan rencana persalinan aman bersama ibu hamil dan keluarganya.
Kesiapan dana persalinan menjadi hal penting dalam perencanaan. Kepastian dan ketersediaan sumber dana secara tidak langsung menjadi faktor yang mempengaruhi kelancaran upaya persalinan. Bidan memfasilitasi hal tersebut dengan memberikan informasi tentang Tabulin atau Dasolin sejak masa kehamilan awal, guna persiapan persalinan yang lebih matang. Namun hanya sebagian masyarakat saja yang merencanakan pembiayaan persalinan bersama bidan (71,9\%). Peneliti menganggap dengan kondisi ekonomi masyarakat Kabupaten Pekalongan yang rata-rata tergolong maju atau mampu, ada kecenderungan sebagian masyarakat mampu mempersiapkan pendanaan secara mandiri tanpa bantuan peran bidan.

Pada tabel 3.2 pengguanaan KB yang direncanakan bersama ibu dan suami juga tidak seluruhnya merencanakan hal tersebut, hanya $75,4 \%$ bidan yang melaksanakannya. Rencana penggunaan metode KB yang tepat pasca persalinan hendaknya sudah direncanakan bersama bidan saat konseling dalam masa kehamilan. Suami atau keluarga juga ikut serta mempertimbangkan rencana penggunaan KB. Dengan demikian manfaat $\mathrm{P} 4 \mathrm{~K}$ dengan meningkatnya peserta $\mathrm{KB}$ pasca salin bisa terwujud.

Tabel 3 Distribusi Sosialisasi dalam Pelaksanaan P4K

\begin{tabular}{|c|c|c|c|c|c|}
\hline \multirow{2}{*}{$\begin{array}{l}\mathrm{N} \\
\mathrm{O}\end{array}$} & \multirow{2}{*}{$\begin{array}{l}\text { Peran Bidan dalam } \\
\text { Sosialisasi }\end{array}$} & \multicolumn{2}{|c|}{ Ya } & \multicolumn{2}{|c|}{ Tidak } \\
\hline & & (f) & $\%$ & (f) & $\%$ \\
\hline 1 & $\begin{array}{l}\text { Bidan mengadakan } \\
\text { penyuluhan kepada } \\
\text { masyarakat }\end{array}$ & 52 & 91.2 & 5 & 8.8 \\
\hline 2 & $\begin{array}{l}\text { Tokoh masyarakat } \\
\text { diikutsertakan oleh } \\
\text { bidan dalam } \\
\text { rencana persalinan }\end{array}$ & 47 & 82.5 & 10 & 17.5 \\
\hline 3 & $\begin{array}{l}\text { P4K dijalankan } \\
\text { dalam wadah lintas } \\
\text { program dan lintas } \\
\text { sektor }\end{array}$ & 46 & 80.7 & 11 & 19.3 \\
\hline
\end{tabular}

Sosialisasi yang diselenggarakan kepada keluarga dan masyarakat telah dilaksanakan dengan baik, sebanyak 52 bidan melaksanakannya. Dengan adanya sosialisasi diharapkan perilaku kesehatan masyarakat akan lebih baik. Hal ini sesuai dengan penelitian lain yang menyatakan adanya perubahan pengetahuan dan sikap setelah 
dilakukan penyuluhan ${ }^{(8)}$. Dalam hal keterlibatan tokoh masyarakat, sebagian bidan menganggap masih kurang $(17,5 \%)$. Secara keseluruhan pelaksanaan P4K belum dilaksanakan lintas program maupun lintas sektor (80,7\%). Penyuluhan berkaitan dengan program $\mathrm{P} 4 \mathrm{~K}$ kepada masyarakat senantiasa dilakukan oleh bidan $(91,2 \%)$. Baik secara langsung kepada ibu hamil, maupun secara tidak langsung melalui forum-forum masyarakat. Sejalan dengan peran bidan sebagai fasilitator bahwa bidan fasilitator setiap bulan mengadakan pertemuan dengan kader dan tokoh masyarakat lainnya ${ }^{(4)}$. Dengan sosialisasi bersama forum-forum dalam wadah lintas program dan lintas sektor. Pelaksanaan P4K banyak mendapatkan dukungan dan bantuan, baik dari perangkat desa, kader, tokoh masyarakat, aktivis masyarakat bahkan seluruh lapisan masyarakat.

Tabel 4 Distribusi Pelayanan dalam Pelaksanaan P4K

\begin{tabular}{cccccc}
\hline $\mathrm{N}$ & $\begin{array}{l}\text { Peran Bidan dalam } \\
\mathrm{o}\end{array}$ & \multicolumn{3}{c}{ Ya } & \multicolumn{2}{c}{ Tidak } \\
\cline { 2 - 6 } & pelayanan & (f) & $\%$ & (f) & $\%$ \\
\hline $\begin{array}{l}\text { Diadakan konseling } \\
\text { bersama ibu hamil, } \\
\text { suami dan } \\
\text { keluarganya } \\
\text { Bidan menolong } \\
\text { persalinan sesuai } \\
\text { standar } \\
\text { Bidan memberikan } \\
\text { pelayanan nifas } \\
\text { sesuai standar }\end{array}$ & 48 & 84.2 & 9 & 15.8 \\
\hline
\end{tabular}

Pelayanan konseling pada ibu/keluarga selama kehamilan telah dilaksanakan oleh sebagian besar bidan dengan persentase $84,2 \%$. Beberapa bidan (46 responden) membantu ibu hamil yang menjalani persalinan sesuai standar. Dilanjut dengan pelayanan pada masa nifas sesuai standar sebanyak 55 responden dengan persentase memuaskan $(96,5 \%)$. Salah satu tugas bidan fasilitator dalam pelaksanaan P4K adalah malakukan konseling/pelayanan kepada ibu hamil. Bidan harus menjelaskan/konseling kepada keluarga tentang pentingnya perencanaan persalinan serta bagaimana mempersiapkan ibu hamil dan keluarga bila terjadi komplikasi kehamilan, persalinan dan nifas. Bidan dituntut untuk memberikan pelayanan KIA sesuai standar dalam antenatal, persalinan, nifas dan KB. Berdasar pada hasil penelitian bidan puskesmas, persentase dalam pelayanan konseling pada ibu hamil menunjukkan bidan telah melaksanakan dengan baik. Hal ini dapat dilihat dari hasil penelitian yang menyatakan sebanyak 48 bidan telah melaksanakan konseling tidak hanya kepada ibu hamil, namun juga melibatkan suami dan keluarga pasien.

Standar dalam pertolongan persalinan yang berlakudi Kabupaten Pekalongan yaitu oleh tenaga kesehatan yang memiliki kompetisi kebidanan $^{(9)}$, yaitu bidan telah mengikuti pelatihan Asuhan Persalinan Normal dan mengaplikasikan sesuai 58 langkah.

Tabel 5 Distribusi Kerjasama Tim dalam Pelaksanaan P4K

\begin{tabular}{|c|c|c|c|c|c|}
\hline \multirow{2}{*}{$\begin{array}{l}\mathrm{N} \\
\mathrm{O} \\
\end{array}$} & \multirow{2}{*}{$\begin{array}{l}\text { Peran Bidan dalam } \\
\text { kerjasama tim }\end{array}$} & \multicolumn{2}{|c|}{$\mathrm{Ya}$} & \multicolumn{2}{|c|}{ Tidak } \\
\hline & & (f) & $\%$ & (f) & $\%$ \\
\hline 1 & $\begin{array}{l}\text { Bidan mengadakan } \\
\text { dan mengelola } \\
\text { kegiatan KIA/KB }\end{array}$ & 41 & 71.9 & 16 & 28.1 \\
\hline 2 & $\begin{array}{l}\text { Bidan } \\
\text { mengikutsertakan } \\
\text { keluarga dalam } \\
\text { menyiapkan } \\
\text { persalinan }\end{array}$ & 45 & 78.9 & 12 & 21.1 \\
\hline 3 & $\begin{array}{l}\text { Bidan } \\
\text { mengkoordinir } \\
\text { persiapan pendonor } \\
\text { darah dan } \\
\text { transportasi untuk } \\
\text { persalinan }\end{array}$ & 35 & 61.4 & 22 & 38.6 \\
\hline
\end{tabular}

Bidan mendorong anggota keluarga untuk ikut serta menolong saat persalinan (78,9\%). Disamping itu 35 bidan juga mengkoordinasikan persiapan pendonor darah dan transportasi proses persalinan ibu hamil. Pengelolaan kegiatan KIA/KB hanya $71,9 \%$ bidan yang menjalankan artinya tidak semua bidan aktif dalam kegiatan tersebut. Pengelolaan kegiatan KIA/KB di Kabupaten Pekalongan berupa kerjasama penyelenggaraan KB safari dan kelas ibu hamil yang dilaksanakan secara terjadwal.

Dalam operasionalisasi P4K harusnya bidan memanfaatkan forum-forum yang sudah ada, bila belum ada maka dilakukan pembentukan dengan melakukan pemilihan warga yang punya waktu dan mempunyai kemauan. Kendala yang ditemukan dalam 
penelitian ini adalah adanya kesibukan pekerjaan masing-masing masyarakat kota yang menghambat berjalannya forum-forum tersebut. Sehingga bidan maupun warga tidak bisa secara rutin mengikuti kegiatan forum masyarakat.

Pengelolaan donor darah dilakukan ditingkat dasar wilayah RT/RW dengan ketentuan calon donor yang ada. Kemudian sarana transportasi didapatkan melalui kesediaan warga untuk pemakaian kendaraannya atau dengan mengadakan pendanaan untuk menggunakan ambulan desa ${ }^{(4)}$. Fakta yang didapat dalam mengkoordinir persiapan pendonor darah dan transportasi untuk persalinan sangat sedikit responden (35 bidan) yang melaksanakannya. Peneliti menganggap masyarakat kurang mengantisipasi terhadap bahaya persalinan, terutama kekurangan darah. Ada kecenderungan pada ibu hamil maupun keluarganya lebih mengandalkan pada ketersediaan di PMI, meski bidan berupaya mengkoordinasikan. Termasuk perihal transportasi/ambulan untuk persalinan, kondisi Kabupaten Pekalongan memiliki kemudahan akses dan sarana transportasi layaknya daerah perkotaan. Sehingga koordinasi pendonor darah dan transportasi yang seharusnya dilakukan oleh bidan tidak sepenuhnya dapat diaplikasikan. Keaktifan masyarakat dalam pemberdayaan berkaitan dengan P4K membutuhkan semangat dan kemauan dan rasa tanggung jawab. Hal ini sesuai dengan pernyataan Cavaye yang menyatakan elemen pemberdayaan masyarakat adalah : 1) kerja sama, 2) kemauan, 3) kepemimpinan, 4) kerja keras, dan 5) organisasi yang terbina ${ }^{(10)}$.

\section{Kesimpulan}

Peran bidan sebagai fasilitator dalam program P4k di Kabupaten Pekalongan telah dilaksanakan dengan baik melalui pendataan yang berulang, namun dalam hal perencanaan pendanaan masih ada sebagian yang tidak mengikuti program yang dirancang oleh bidan dikarenakan kondisi ekonomi masyarakat Kabupaten Pekalongan yang baik sehingga masyarakat dapat mempersiapkan sendiri pendanaan secara mandiri.

\section{Daftar Pustaka}

[1] Kemenkes RI, Infodatin: Pusat Data dan Informasi Kementrian Kesehatan RI, Jakarta, 2014

[2] Dinas Kesehatan Provinsi Jawa Tengah, Profil Kesehatan Provinsi Jawa Tengah Tahun 2015, Semarang 2015

[3] Wardani DS, Kapatuhan Bidan Praktek Swasta dalam Pelaporan Pencatatan Pelayanan KIA di Kabupaten Blitas Provinsi Jawa Timur Tahun 2009, Universitas Diponegoro, 2009

[4] Depkes RI,Pedoman Program Perencanaan Persalinan Dan Pencegahan Komplikasi Dengan Stiker. Jakarta: Departemen Kesehatan Republik Indonesia, 2009.

[5] Rosyida R, Maslikhah, Suwondo, Gambaran Perilaku Ibu hamil dalam Pelaksanaan Program Perencanaan Persalinan dan Pencegahan Komplikasi (P4K) di Wilayah Kerja Puskesmas Wonokerto 01 Kabupaten Pekalongan. Jurnal Kebidanan 07 (01) 1-114, 2015

[6] Prasetyawati AE, Kesehatan Ibu dan Anak (KIA) dalam Milenium Development Goals (MDGs). Yogyakarta: Nuh Medika; 2012

[7] Kapti, Rinik Eko, Yeni Rustina, and Widyatuti Widyatuti, Efektifitas audiovisual sebagai media penyuluhan kesehatan terhadap peningkatan pengetahuan dan sikap ibu dalam tatalaksana balita dengan diare di dua rumah sakit kota Malang, Jurnal Ilmu Keperawatan $1.1,2013$

[8] Runjati, Asuhan Kebidanan Komunitas. Jakarta: EGC, 2011

[9] Dinas Kesehatan Kabupaten Pekalongan, Profil Kesehatan Kabupaten Pekalongan Tahun 2014, Kabupaten Pekalongan, 2015

[10] Suprapti, Sriatmi A, Faktor-Faktor yang Berpengaruh dengan Upaya Pemberdayaan Masyarakat oleh Bidan Terkait dengan Program P4K di Kabupaten Pasuruan, Jurnal Penelitian Kesehatan Suara Forikes Volume II Nomor 4, 2011. 